A major purpose of the Technical Information Center is to provide the broadest dissemination possible of information contained in DOE's Research and Development Reports to business, industry, the acaciemic community, and federal, state and local governments.

Although a small portion of this report is not reproducible, it is being made available to expedite the availability of information on the research discussed herein.

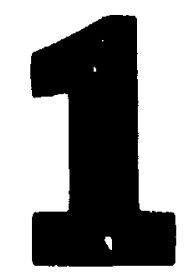


LA-UA - $-85-3252$

CiNt:SSIIKt--9

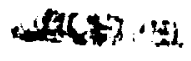

$0,1,1, \ldots+$,

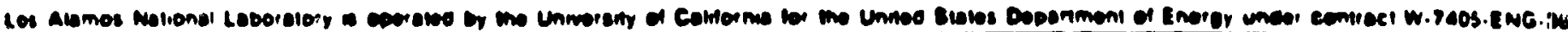

LA-UR- $-85-3252$
TITLE
$\begin{aligned} & \text { Testing Site Size Requirements in Chemisorption: Experiment and } \\ & \text { Theory }\end{aligned}$

AUTHOR(S) Charles T. Campbel1, Mark T. Paffett, and Arthur F. Voter

SUBMitTED to Journal of Vacuum Science and Technology

\section{DISCLAIMER}

This renort was prepared as an account of work sponmered by an ugency of the Unitol Statea Government. Neither the Inited States (jovernment nor uny ugency thereof, nor uny of their emplo; ass, makes any warranty, express or ienpliod, of ussumen uny legal liability or renponsi. bility for the uccuracy, completeness, of usefulneas of any information, upparutus, product, or process disclosed, or represents that its use would not infringe privalely owned rights. Reforence herein to any specific commercial product, process, or nervice by trade name, trudemark. manufacturer, or otherwise does not necessarily constitute or imply itn endorso'nell1, recommendation, or favorina by the I/nited States fovernitient of any unency thereof. The viewn and opinions of authors expressod herein do nos necensurily state of reflect thane of the United States Ciovernment or any agency thereof. 


\title{
TESTING SITE SIZE REQUIREMENTS IN CHEMISORPTION: EXPERIMENT AND THEORY
}

Charles T. Campbell, Mark T. Parfett, and Arthur F. Voter

Los Alamos Hational Laboratory

Los Alamos, NM 87545. USA

\begin{abstract}
"Enserble requirements" In surface chemistry refer to the number and shape of contlguous ompty oltes necessary for chemlsorption of a particular molecule. Enser.ole effects can play a wajor role in directing the course of surface reactlons, leading, for example, to dramatlc changes in catalytic selectivlty when the actlve metal component is dlluted upon alloylng with an !nert metal. We Wll revlow here fundamental surface sclence stucies that have attempted to probe thls slte size requirement by diluting actlve sites on a single crystal surface with ar Inert melal overlayer. In these studles, Inltial stlcklni probabllity and saturation coverage are measured as a fitnctlon of diluent metal coverage. We will emphaslze recent resulty in our lab on the intcraction of slmpile orslecules $\left(\mathrm{CO}, \mathrm{H}_{2}, \mathrm{O}_{2}\right)$ Wleh $\mathrm{Cu}-, \mathrm{AE}^{-}$, and $\mathrm{Bl}$-dosed $\mathrm{Pl}(111)$. These show that the Croup IA Melads $(\mathrm{Cu}, \therefore \mathrm{B}$, Au) are pour dlluents since thry cluster Into two-dimensional Islands. We find that adsorbed Bl opreads out unirormly over the iurfuce and efrectively lests ensemble sizes. Theoreldet modeds bistid

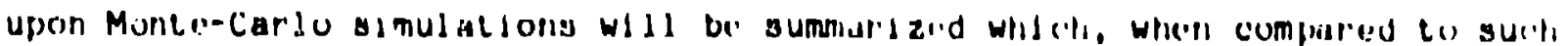

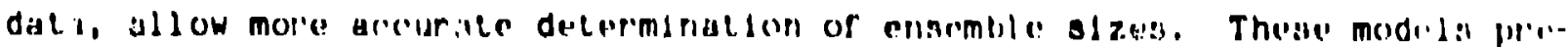
ddic unliake curves that devlate strongly from the eommondy used $(1-0)^{A}$ Jath

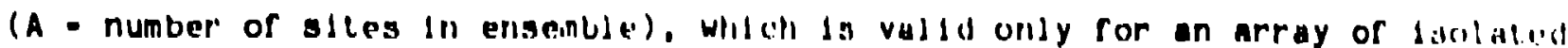
ensemulas.
\end{abstract}




\section{INTRODUCTION}

An ensemble requirement refers to the size and shape of sttes that are necessary for chemisorption or a reaction step at a surface. In a Langmulrlike adsorption model, for example, the rate or acsorption may be expressed as $\left(1-\theta_{A}\right)^{A}$. where $\theta_{A}$ refers to the coverage or the fraction of occupled sites, and A refers to the number of contlguous free sites, or the ensemble size, requlred for that adsorbate.

In hydrocarbon reactions for the petroleum industry, the selectivity of certain catalysts has been tuned by controlling the number of contiguous oltigs avallable on the surface [1-4]. This can be done by decreasing the particle slze of a supported metal down to clusters of a rew atoms [4] or by diluting the active metal with the addition of a second, inert metal such as $A u[1-4]$. For example, selectlvity to dehydrogenation over hydrogenolysls or hydrocarbons can be Increased by dlluting $\mathrm{N} 1$, Ru, or Os catalysts with $\mathrm{Cu}[1-4]$. This has been explalned in terms or an ensemble effect, whereby hydrogenolysis reactions require a larger group of actlve metal atoms to accommodate the rragments rusulting from $\mathrm{C}-\mathrm{C}$ bond cleavage. Only $\mathrm{C}-\mathrm{H}$ bonds are broken in dehydrogenation reartiong. Many other examples have been mentloned in recent excullent rovlewis (1-4). Thus, there is a strong practical motlvation ror developlng a rundamenlal understanding or engemble efrects in surface reactioni.

Ono of the must Important barrlers In underscinding ensemble efrecta in-

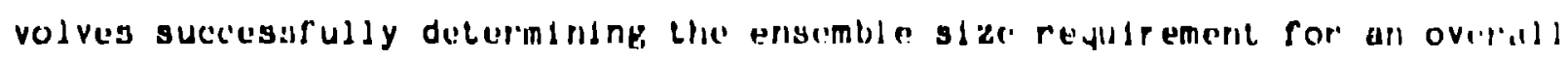

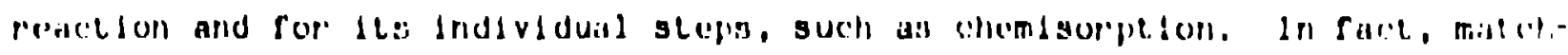

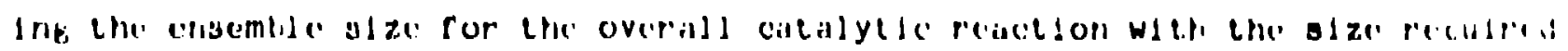


for Individual steps could be an elegant method for specifying the ratedetermining step in a reaction mechanism. Most results to date have been obtalned by masking sites of the active metal with inert specles, and observing the resulting effects on adsorption and reactions with the molecule of Interest [5-20]. Early work along these lines has usso bulk alloys of the active metal and a second, Inert metal $[5-8,16,17]$. For detalled understanding, surface analysis is absolutely required here, since the surface composition of the alloy rarely reflects that of the bulk $[3-4,7]$. Another convenlent method Involves vapnr-napns! Ine an lncrt specles, such as $A u, A B$, or $C u$, onto the surface of the actlve metal. Here, the whole range of surface compositions is easliy attalned in a well-characterlzed way. Recently, much work has appeared uslng thls met.hod $[9-15,18-20]$. It is important to choose the masking atom so that its electroriegativity matches that of the actlve metal, to minlmize electronlc effects. We have recently found one of the major shortcomings of this techndque: the Group IB metals tend to show altractlve lateral Interactions, coalescing into two-dimenslonal lslands on the surface [19-21]. It unfortunately leaves large .eglons essentlally free of the blocklng agent, and the reaction rate or the adsorbate coverage falls only linearly whth the coveragc of the masklnB agent $(A U, \lambda B$, or $C U)(12-15,18-20)$. Th1s can easlly be misinterpreled as indlcallng an engrmule slze of one slte for the reaction of intere.s.

Another problum thit has porglgled in studylug engemble slzes in thas hily is the lark of a good theoretleal rormaldsm wlth when to match the dith. Eiven

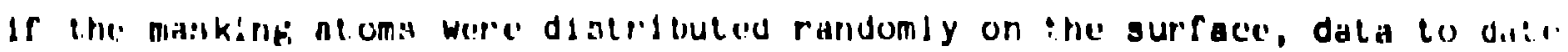


[5-21] have almost exclusively been modeled assuming completely 1solated (nonoverlappling) ensembles of oltes for the adsorbate and a random distribution of the mesking agent, whlch blocks only one site. Inls leads to an expression $[5,6,16,21,22]$ where the Initlal sticking probabllity $\left(S_{1}\right)$ or saturation coverage $\left(\theta_{A}^{s a t}\right)$ of the adsorbate molecule varles with Inert metal coverage as:

$$
S_{1} \text { or } \theta_{A}^{s a t} \propto\left(1-\theta_{N_{i}}^{A}\right.
$$

Here, $\theta_{M}$ is the rractional coverage of the inert, masking atom and $A$ is the number of contlguous sltes (ensemble) requlred for adsorption of the molecule or Interest.

In reality, for $A>1$ the adsorhate sltes can overlap and do, so that E4. (1) Is signiflcantly in error for large A. In ar, early work, Herington and Rideal [22] recognlzed this difficulty and perfurmed a few slmple Monte-Carlo ralculations that eliminated thls assumption of overlapplng sites. Their results Indlcated that, Indeed, Eq. (1) is greatly in error for large A. Unfortunately, that work has been largely I gnored unt1l now.

In thls paper we wlil review results of our receni, accurale Monie Carlo calculations, where the adsorbate sltes are allowed to ruldy overlap, and the adsorbed molecules are allowed to $\mathrm{ml}$ grate and re-orlent on the surface. A complete presentalion or thesc resules wli] apprar elsewhere [aj], where a large ranper of posslole geomelides are examined. We wlll also compare inesile

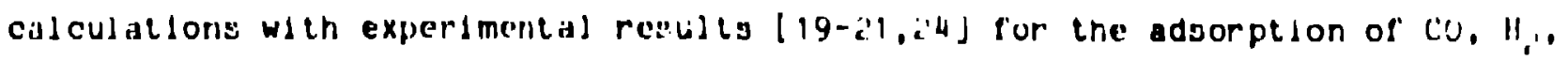


and $\mathrm{O}_{2}$ on $\mathrm{Ag}, \mathrm{Cu}$, and $\mathrm{Bl}$-masked $\mathrm{Pt}(111)$ surfaces. This comparison has allowed a determination of the ensemble size required for adsorption, as well as the size of the ensemble that is masked by each B1 atom. B1smuth is shown to be preferable to the Group IB element.s as a masking agent, since it shows weakly repulgive lateral interactions and therefore tends to spread undformly across the surface.

\section{EXPERIMENTAL}

Preparation and cleaning of the Pt(111) slngle-crystal are described in a previous publication [19]. The BI vapor-deposition technlque and experimental arr. ngement are also descrlbed therein [21]. Auger electron spectroscopy. Low-energy electron diffraction (LEED), and thermal desorpt on mass spectroscopy (TDMS) were conducted using conventlonal apparatus [19,21].

\section{THEORY}

The Monte Carlo slmulatjons were carrled out on both square and hexagonal lattlces, using a $58 \times 58$ gric of binding sites. To eliminate edge eifects, all propertles were computed from a $50 \times 50$ grld centered within the $58 \times 58$ lattlce. A case was deflned by choosing the lattlce type, a slze (M - number of binding slies) and shape (conrlguration or blinding sltes) for the nasklng agerit, and $3 \perp z e(A)$ and shape for the adsortiss molecule. Nota that for some shapes, more than one orlentation 1 s possible. For each case, the saturatiun cuverage of the adsorbale wlth no difiusion aljowed ( $\cup_{A}^{9 a t}$ nd , the saturation coverage allowing adsorbale clrfusion $\left(\theta_{A, d}^{\text {sat }}\right)$, and the Inltlal stleklng probablllty $\left(s_{1}\right)$ were determlned as a functlon of the pre-coverage of the maiklng 
molecules $\left(\theta_{M}\right)$. To obtain these values with statlgtical error bars $(<0.18)$, 100 independent Monte Carlo 31 mulations were performed for each value of $\theta_{M}$. The following describes the procedure for one such simulation.

The first stage consists of spraying down a coverage $\theta_{M}$ of 1 mobilie maskIng agent. This is accomplished by repeatedly choosing a random position and orlentation on the grid until the desired number of mask agents is generated. Each tIme this location overlaps an existing mask agent, the choice is discarded. (Two specles "overlap" if they share one or wore binding sites.) Note that the maximum value of $\theta_{M}$ that can be achleved in this manier is less than one, unless the mask agent uses only one binding slte.

The initial sticking probability for this $\theta_{M}$ is determined by repeatedly attempting to place an adsorbate in a random position and orlentation un the masked lattice, removing the adsorbate molecule before the next attempt. $S_{1} 1 s$ computed as the fraction of attempts that lead to no overlap with mask agents.

To determire $\theta_{A}^{s a t}$, nd adsorbate molecules are sprayed down randomly, allowIng each new adsorbate to "stick" only if it overlaps no existing mask or adsorbate. Thls is continued untll there are no more "holes" that can fit an adsorbate molecule. (Hereafter, this is the definition of a nole.)

Starting from a configuration in whlch all holes have been filled, the value for $\theta_{A, d}^{\text {sat }}$ is decermined by aljowling the adsorbate molecules to diffuse, and fllling any new holes that open up. An attempted difluslon move conslsts or selectlne, at random, an exlsting adsorbate molecule, a displacenent, and a new orlentation. If placine the adsorbate in this new position causes no overlap with anther molecule, the move $1 \mathrm{~s}$ accepted. The immedlate region is then searched for holey, whlch, if round, are fllled wllh a new adsorbate molecule. 
There is no need to search for a hole if the move is rejected. The maximum distance and direction of an attempted suove is 11 mited only by the slze of the molecule. Since all noles are fllled as they are created, woves that leac to no overlap between the old adsorbate position and the new adsorbate position need not be attempted. The diffusive moves are repeated until $\mathrm{N}_{\max }$ successful moves are carried out without a new hole belng filled. In the present study, $\mathrm{N}_{\max }$ was taken as twenty times the number of possible moves of the system (each time a hole was filled the nimber of posslble moves of the system was recoriputed using a systematic scan). This is by far the most time-consuming stage of the simuiation.

Based on tests varying the lattice size and the convergence criterla, these calculations appear to be accurate to within a few percent. Full details are presented elsewhere [23].

Coverages $(\theta)$ here are defined such that $\theta-1$ corresponds to one per s inface site. Thus, the maximum possible coverages are $\theta_{\Lambda} \cdot 1 / A$ and $\theta_{M}=1 / M_{\text {; }}$ a:id, $\theta_{M}^{*}-M \theta_{M}$.

IV. GENEKAL THEOHETICAL RESULTS

Example results for a hexagonal lattlce of sites are shown in Figs. 1 and 2. for an adsorbate requiring seven sites ( -7 ) and for masking agent sizes $(M)$ of one and geven, respectively. If $M-1$, the Initial stickine probibllity is rlgorously given by the $\left(1-M \theta_{M}\right)^{7}$ expression of Eq. (1). However, the true saturation adsorbate coverages $\theta_{A, d}^{\text {sat }}$ and $\theta_{A}^{\text {sat nd }}$ disagree with this expression by up to a factor of three in Inltial slope. Remember that Eq. (1) predicts $\cup_{A}^{S a t}$ under the assumptions of Isolated ensembles for the adsorbate and a random 
distribution of singly masked sites. This disagreement with our results shows the error in these assumptions. When $M$ is large, errors as large as a factor or two result in the initial sticking probability as well, with even larger errors for $\theta_{A}^{\text {sat }}$. Thus, the assumptions of Eq. (1) would lead one to extract ensemble sizes too small by a factor of two to three, depending upon whether one was fitting data for $S_{1}$ or $\theta_{A}^{\text {sat }}$. The error in $S_{1}$ results solely from the assumption that the masking agent raidomly blocks single sites, and not ensembles of contiguous sites.

Results of the type shown in Figs. 1 and 2 have been computed for hexagonal lattlces for $A-1$ to 7 and $M-1$ to 7 and for square lattices for $A-1$ to 5 and $M=1$ to 5 . These results, which wlll be presented in detall elsewhere [23], show the same trends as above and allow the following further gene:al conclusions to be arawn.

(1) When attempting to determine ensemble sizes, choosing a masking agent as small as possible provides the greatest distinction between ensemble requirements. This will also be true in iuning selectivity of catalysts by this wasking method. Essentlally, flnite ensemble slzes for the mask (M)1) resemble 1 slands of single-site masking agents, and in the limit of large $M$, no distinctlon between A values wouid appear.

(2) Fitting $S_{1}$ data distinguishes ensembie sizes more readily thar. $\theta_{A}^{\text {sat }}$ data (see caveat below).

(3) For $A>1, \theta_{A}^{s a l}$, id 15 always less than unity even when $\theta_{M}=0$, due to ranjon generalion of free ensembles too small for the adsorbate. This point has been nuted before $[22,25-26]$. 
(4) The saturation coverage with diffusion always has a steeper initial slope than without diffusion, although the curves get very close when $M \theta_{M} \geq 0.4$. Nelther drops as steeply as the prediction of Eq. (1).

(5) Down to very lo'd values of $\theta_{A}^{\text {sat }}$, nd $(\leq 0.2)$, this curve is almost linear Even for large A, in distinct contrast to the curvature of Eq. (1). This was noted previously $[22,25]$.

(6) Eq. (1) is only valid for $\theta_{A}^{\text {sat }}$ when $A-1$.

\section{v. EXPERIMEN: ¿ RESULTS}

We have recentiy shown [21,24] that the submonolayer growth mode of $B i$ on $\mathrm{Pt}(111)$ results in hexagonal overlayer structures with $\mathrm{Bl}$ adatoms maximizing thelr nearest neighbor distances due to lateral repulsive forces. Briefly summarizing, BI deposition at $-600 \mathrm{~K}$ is observed by LEED to produce in succession $p(2 \times 2),(\sqrt{3} \times \sqrt{3}) R 30^{\circ}, p(3 \times 3)$ ard $p(4 \times 4)$ patterns consistent with proposed models $[21,24]$ glving Ideal coverages $\left(\theta_{B 1}\right)$ of $0.25,0.33,0.44$, and 0.56 , respectively. The $p(4 \times 4)$ pattern at $\theta_{B i}=0.56$ corresponds to a closepacked $B 1$ overlayer. Below ${ }_{B 1}=0.25$ nO LEED features are seen and therefore Bl may be randomly dispersed on the Pt(111) surface. For coverages greater than 0.56. three dimensional $19 \mathrm{lands}$ begin to form. It is difficult to teil if these Islands are pure BI or BI/Pt allojg, as they cover a small fraction of the surface [24]. A more exhaustive descrlption of the growth modes, as wel] as their varlaticn with temperature, is contained in our recent results [ 21 , 24]. The submonolayer growth inode behavior for Bi/Pt(111) is to be contrasted with the growih mode behavior exhlblted by Group IB transition metals (CU, AE. 
$A u)$ on $\mathrm{Pt}(111)$, namely, large two-dimensional 1 sl and formation in the submonolayer region [15,18-20]. Thls difference makes $B 1$ a much better cholce as a masking agent for testing ensemble sizes, as described below.

In Fig. 3a the integrated thermal desorption spectra for saturation exposures of $\mathrm{CO}$ and $\mathrm{H}_{2}$ are shown plotted as a function of $\mathrm{Bl}, \mathrm{Cu}$, and $\mathrm{AB}$ precoverage. The saturation $c 0$ exposure at $275 \mathrm{~K}$ was shown to produce a $c\left(\begin{array}{lll}4 & \times 2\end{array}\right)$ pattern on the clean $\mathrm{Pt}(111)$ surface consistent with $\theta_{\mathrm{CO}}^{\text {sat }}=0.5[27-28]$. The $\mathrm{H}_{2}$ TDMS for a saturation exposure at $150 \mathrm{~K}$ on clean $\mathrm{Pt}(11)$ was in good agreement with literature data [27-28]. Saturation exposure of $\mathrm{H}_{2}$ Bives $0.8 \mathrm{H}-$ adatoms per Pt surface aton [29], with $p(1 \times 1)$ filling of three-fold hollow sites $[30]$.

For $A B$ and $C u$, both $C U$ and $H_{2}$ are blocked in a one-to-one rashion, consistent with the two-dimenslonal islanding of $\mathrm{Ag}$ and $\mathrm{Cu}[19-20]$. For the $\mathrm{Bl}$ modifled surfaces the attenuation in the uptake of $\mathrm{H}_{2}$ is notably different from that seen for $C O$ and reflects the different enssmble sizes involved. The solid lines in Fig. 3a represent our Monte Carlo calculatlons for saturation coverage allowing surface diffusion for the cases: a) M $=4, A=2$; b) M $=4$, A - 1; and $c) M=2, A=2$.

In Fig. 3b the amount of nolecularly adsorbed $\mathrm{O}_{2}$ for a saturation exposure at $110 \mathrm{~K}$ is shown plotted versus B1 precoverage. The amount of mulecularly adsorbed $\mathrm{O}_{2}$ was determined by summine the integrated TDMS (M/e - 32) traces for the desorption of molecular $\mathrm{O}_{2}$ occurring at $150 \mathrm{~K}$ and for the desorption of $\mathrm{O}_{2}$ from the atomle state at $-700 \mathrm{~K}[21]$. The atomically adsorbed oxygen results from dissociation of that fraction of molecular oxygen that does not desorb and has beten shown [31] to occur on] y upon heatlne the sample atove $-150 \mathrm{~K}$. Thus, 
the coverage of oxygen we plot here reflects only molecularly adsorbed $\mathrm{O}_{2}$ at $110 \mathrm{~K}$. For clean $\mathrm{Pt}(111)$, the saturation coverage of $0_{2, a} 1 \mathrm{~s} 0.4$ molecules per Pt surface aton [31].

Fuli detalls of the interactions of $\mathrm{CO}, \mathrm{H}_{2}$ and $\mathrm{O}_{2}$ Wlth $\mathrm{B} 1 / \mathrm{Pt}(111)$ will appear elsewhere $[21,24]$.

\section{DISCUSSION}

The theoretical nodels shown in Fig. 3 provide a gond fit to the experimental data at $\mathrm{loH}$ B1 coverage for molecular $\mathrm{CO}$, dissoclative $\mathrm{H}_{2}$ and molecillar $\mathrm{O}_{2}$ adsorption on $\mathrm{Pt}(111)$. These models assume ensemble sizes for the adsorbate of tinc, one, and two sites, respectlvely, which ls consistent with the satura$\$ 10$ in coverages of these spec:es $(0.5[27-28], 0.8[29]$, and $0.4[31 \mathrm{j})$. It is further assumed that each $\mathrm{Bl}$ adatom blocks two such gites for $\mathrm{CO}_{\mathrm{a}}$ and four such sites for $\mathrm{H}_{a}$ and $\mathrm{O}_{2, a}$. We also illow $\mathrm{CO}_{a}$ and $\mathrm{C}_{2, a}$ to difruse, al though the differences are almost undlstingulshable if diffusion is disallowed. (When $A$ 1. there is no difference.) As can be seen in Fig. 3, there is almost no distinction between the $A=1$ and $A=2$ models wren $M=4$, so that our data cannot actualiy distinguish these ensemble sizes. This emphasizes the desirability of choosing small M. Finding a masking agent with $M-1$ and no electronic ligand effects is a challenge to surface sclence.

The data for $\mathrm{O}_{2, a}$ and $\mathrm{H}_{\mathrm{a}}$ In F18. 3 would have been equally well modeled using $A=M=3$ (with dirsusion). We have rejected such models since the situration coverages of these species on clean $\mathrm{Pt}(111)$ Indlcale ensemble sizus A - $?$ and 1, respectlvely, and not 3. An Important point here is that elther sultable theorelical model differs slgniflcantly from that predicted by Eq. (1), whlch would require $A-M=2$. In thls case, the error appears as a 
factor of two in $M$, the ensemble masked by B1, but for larbe acsortates the error would appear in the value of $A$. In understanding blgetallic catalysts, both values are equally important.

An Important polnt indicated by these results is that a gen masking agent can poison a different number of sites depending upon the adsorbate ior reaction) of interest: $M=2$ for $\mathrm{CO}_{a}$ and 4 for $\mathrm{H}_{a}$ and $\mathrm{O}_{2, a}$. How this can arise is Indlcated by the Insert of F1B. 3b. A lattlce of Pt-słze "sites" are shown by nollow spheres $(r=1.39 \AA)$ and the $B 1$ adatom by a larger rilled sphere $(r=1.84 \&[32])$. The location of the "g1tes" is not necessarily "a-top"; and this lattlce could be translated across the Pt(111) iattice to place the "sites" In any arbitrary locatic,. For the BI location as shown, two sites will clearly be blocked for all adsorbatus. However, two other sltas are only slightly covered, so that they may or may nct be masked, depending upon the adsorbate

The nonlinearity in the data of Fig. 3 for larger $\theta_{B 1}$ is not flt bj the theoretlcal models we have used, and in general occurs for ldeal cases in $\theta_{A}^{\text {sat }}$ only for very large A [23]. We reel that the nonlinearlty occurs here secause of the fact that $B 1$ adatcms change their location as coverage grows, consistent Wl th our structural models based on LEED data [21,24]. Note that the saturation BI coverage is $0.56[21]$, so that each B1 atom only blocks about two sltes for lts own adsorption. Further nonlinearlty arlses from nonhomosoneous B1 coverage across the surface [24], and from the facl that nultllayer B1 growth already begins by $\theta_{B d} \geq 0.25[24]$. For these reasons, it 19 advised lo rit data only at low $U_{M}$ (Inltlal slope) in determinlng ensemble slzes. Alsci, in this low coverage rangc, the assumpition of randomness is most valdd. 
We noted in Section III that for the Ideal case, fitting $S_{1}$ data provides the greatest distinction between adsorbate sizes. However, a strong warning is advised herel If the lmpinging gas molecule, upon hitting a masking atom, is able to deflect into a free slte or enter a weakly bound precursor state in which it can diffuse to sind a a free site, the theory here is invalid. Determining the exient of such pnenomena is almost lmpossible except when the precursor state $1 \mathrm{~s}$ so long-lived that $S_{1}$ mimics $\theta_{A}^{\text {sat }}$. Thus, it is advised to model $\theta_{A}^{s a t}$ data, whlch is more easily obtalned anyway. Determining whether diffusion can or cannot occur may be difficult for a given adsorbate. Using the highest temperature before desorption or dissoclation occurs is advised. Fortunately, the ensemble olze for an adsorbate found from 1 ts absolute saturation coverage on a clein surface wlll only agree with that found uslng the masking technique for large A if thr proper assumption about diffusion is used. For example, if diffusion were disallowed the data would actually obey the curve for $\theta_{A, \text { nd }}^{\text {sat }}$ of Flg. I (M- 1, A - 7). Falsely assuming that diffusion were allowed would lead to values of $A=4$ and 10.5 by the two methods. Thus, comparlng the two methods allows accurate determination of bo: the ensemble size and the particlpation of difrusion by the adsorbate. 
VII. REFERENCES

1. J. H. Sinfelt and J. A. Cusumano, In Advanced Materials in Catalysis, eds. J. J. Burton and R. L. Garten (Academic Press, N.Y., 1977) p. 1.

2. W. M. Sachtler, Chemtech, July 1983, 434.

3. W. M. Sachller and R. A. van Santen, hdvan. Catal. 26 (1977) 69.

4. V. Ponec, Advan, Catal. 32 (1983) 149.

5. K. T. YU, D. T. LIng and W. E. Spicer, J. Catal. 44 (1976) 373.

6. J. J. Burton and T. M. Pugel, J. Catal. 47 (1977) 280.

7. J. J. Burton and E. Hyman, J. Catal. 37 (1975) 114.

8. K. Chrlstmann and G. Ertl, Surface Sc1. 33 (1972) 254.

9. J. C. VIckerman, K. Christmann and O. Ertl, J. Catal. I1 (1981) 175.

1C. H. Shimizu, K. Christmann and G. Ertl, J. Catal. 61 (1980) 412.

11. J. C. Vickeiman and K. Christmann, Surface Sc1. 120 (1982) 1.

12. J. S. Foord and P. D. Jones, Surface Sc1. 152-153 (1985) 487.

13. J. T. Yates, C. H. F. Peden and D. W. Goodman, J. Catal. (In press).

14. H. C. Peebles, D. D. Beck, J. M. Whlte and C. T. Campbell, Surface Scl. 150 (1985) 120.

15. P. W. Davies, M. A. Quinlan and G. A. Somorjal, Surface Sc1. 121 (1982) 290.

10. D. D. Eley and P. B. Moore, Surface Sc1. 111 (1981) 325.

17. F. Chehab, W. Kirsteln and F. Thleme, Surface Sc1. 108 (1981) L419.

18. R. Yeates and G. A. Somorjal, Surface Sc1, 134 (1983) 729.

19. M. T. Parfett, C. T. Campbell, T. N. Taylor and S. Srinlvasan, Surface Sc1. 154 (1981) 284 .

20. M. T. Parretl, C. T. Campuedl and T. N. Taylor, Langmulr (In preys).

21. M. T. Parfett, C. T. Campledl and T. N. Taylor, J. Vac. Sc1. Technol. $\underline{13}$ (1S85) 812. 
22. E. F. G. Herington and E. K. Rideal, Trans. Faraday Soc. 40 (1944) 505.

23. A. F. Voter and C. T. Campbell, in preparation for Surface Sc1.

24. M. T. Parfett and C. T. Campbe1l, In preparation for Surface Sc1.

25. A. Verma and D. M. Ruthven, J. Catal. 46 (1977) 160.

26. L. L. Hegedus and R. W. McCabe, Catal. Rev.-Sc1. Eng. 23 (1981) 377.

27. G. Ert1, M. Neumann and K. M. Strelt, Surface Sc1. 64 (1977) 393.

28. H. Stelninger, S. Lehwald and H. Ibach, Surfaci Sc1. 123 (1982) 264.

29. K. Christman, C. Ertl and T. Plenet, Surface Scl. 54 (1976) 365.

30. (a) J. Lee, J. P. Cowin and L. Wharton, Surface Sc1. 130 (1985) 1;

(b) I. Batra, Surface Sc1. 137 (1984) 1.97.

31.(a) J. L. Gland, Surface Sc1. 93 (1980) 487;

(b) J. L. Gland, B. A. Sextion and G. B. Flsher, Surface Sc1. $95(1980)$ 587.

32. C. T. Campbeli, submitted to Surface Scl. 


\section{FI GURE CAPTIONS}

Figure 1. The saturation coverage with surface difrusion ( $\theta_{g \text { sat }}^{\text {nat }}$ ), and the Initial stlcking probablilty $\left(S_{1}\right)$ determined from Monte Carlo calculations for the masking agent requiring 1 ol te $(M-1)$ and adsorbate requiring 7 sites $(A-7)$. The predictions for $S_{1}$ and $\theta_{A}^{\text {sat }}$ assuming 1 solated ensembles of sites (Eq. 1; is also shown.

Flgure 2. Same as F1g. 1, only M-A-7.

F1gure 3. (A) Sacuration coverages of dissociatlvely adsorbed hydrozen and molecularly adsorbed $\mathrm{CO}$ as a function of metal precoverage. The data from the B1/Pt(111) interface are shown as actual points. The generallzed result for $\mathrm{Ag}$ or $\mathrm{Cu}$ on $\mathrm{Pt}(111)$ is shown as a dashed Iine. Hydrogen was dosed at $150 \mathrm{~K}$ and carbon monoxide at $275 \mathrm{~K}$. The solid lines are the theoretical curves computed as described in text for cases; (a) $A=2, M=4$; (b) $A=1, M=4$; and (c) $A=2, M=2$. (B) Saturation coverage of molecularly sodsorbed $\mathrm{O}_{2}$ on $\mathrm{Pt}(111)$ as a function of BI precoverage. The solid line (d) 1 is the theoretical curve for the case $A=2, M=4 . O_{2}$ was dosed at $110 \mathrm{~K}$. Inset: a lattlce of Pt-sized sites with a single BI adatom, showing how it could block two or four sites, depending upon the nature of the adsorbate. 


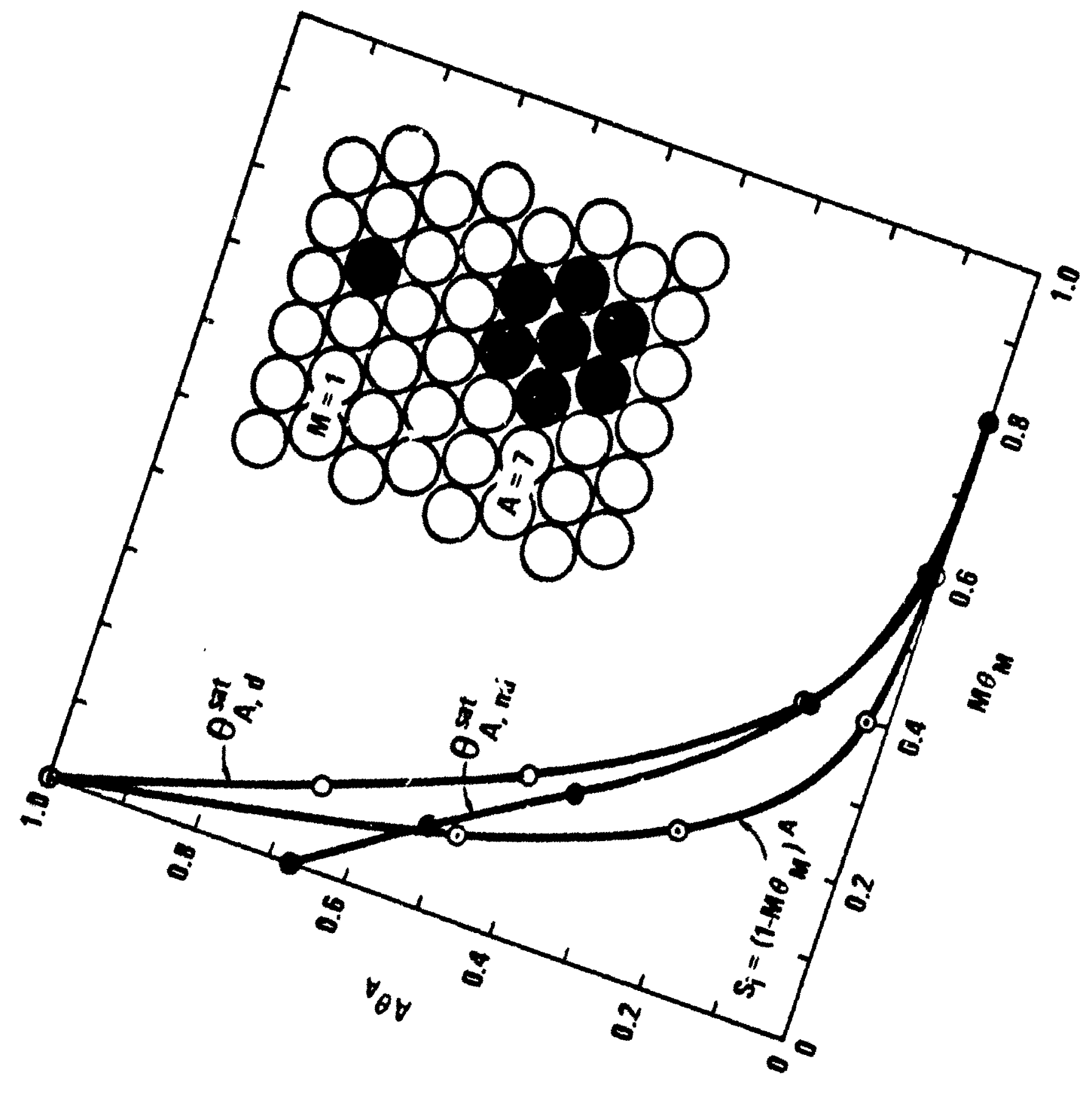

Fi. 1 


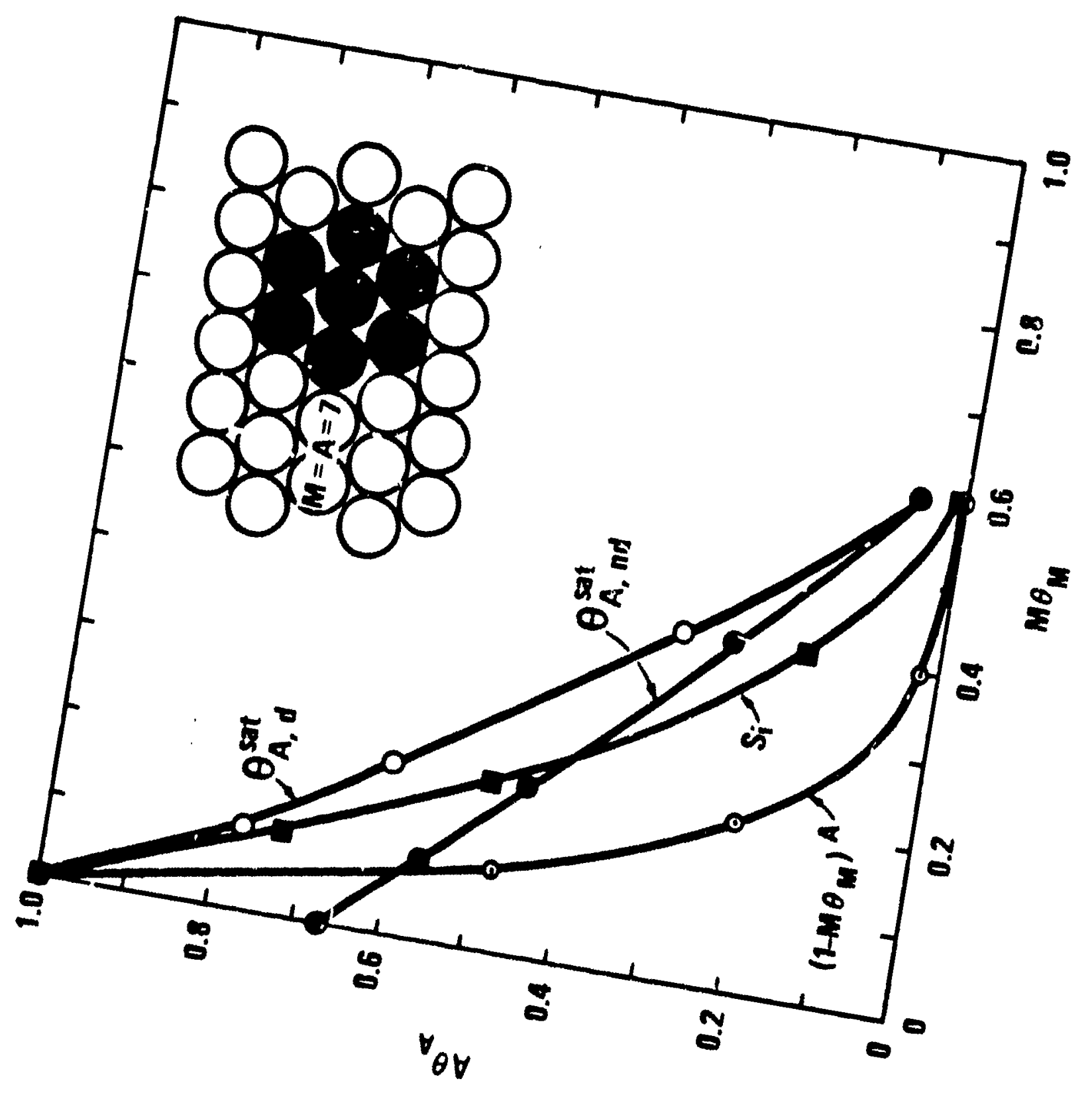

fin. 7 


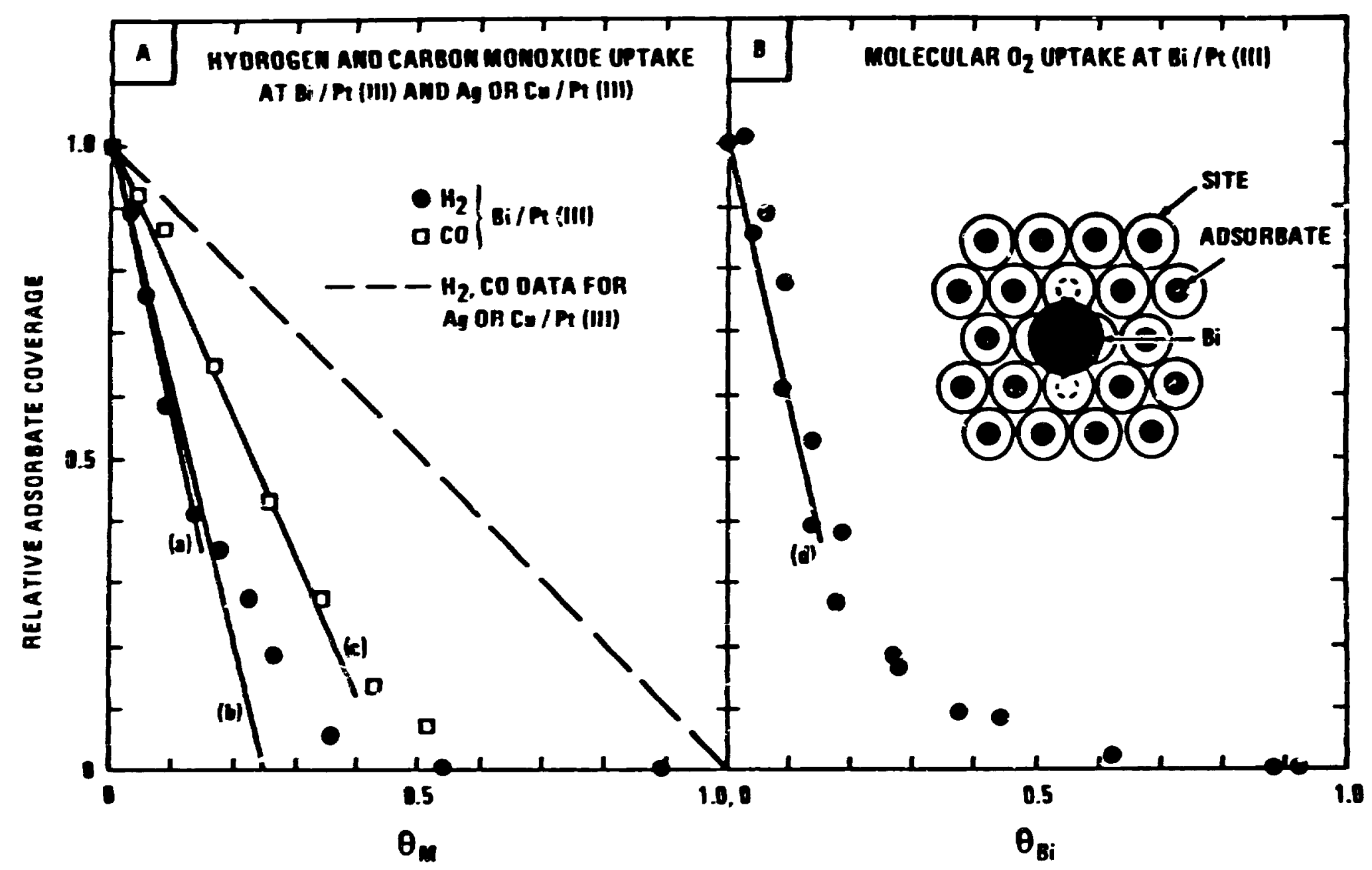

" 